\title{
THE
}

\section{NATAL SPECIES OF THE SAPINDACEAE.}

\author{
By E. P. Phillips, M.A., D.Sc., F.L.S., Botanist in Charge of the \\ National Herbarium, Pretoria.
}

During a short stay in Durban in January, 1919, I saw for the first time, in their native state, species of Sapindaceae growing in the Stellabush. This led me to make an examination of the material in the Natal Herbarium, and at the same time I took the opportunity of describing the species. To make the records more complete than it was possible to do from the material in the Natal Herbarium alone, all the Natal specimens in the Bolus Herbarium and Cape Government Herbarium at Capetown and the National Herbarium, Pretoria, were examined. This has added considerably to the Natal localities in which the species occur.

Twelve genera of the order Sapindaceae have been recorded from South Africa, and of these nine occur in Natal. Wood, in his "Handbook to the Natal Flora" (1907), cites sixteen Natal species, but he eventually dropped Schmidelia natalensis in his "Revised List of the Natal Flora." Of the fifteen species mentioned by Wood, only ten are represented in the Natal Herbarium, and of those unrepresented I have not seen specimens from Natal in any other herbarium.

The examination of the material has brought to light an undescribed Bersama which occurs in Natal, and I am of opinion that Bersama tysoniana also occurs there, though I have seen no Natal specimen.

\section{KEY TO THE GENERA.}

Stamens eccentric. Fruit bladdery. A twiner.............. Cardiospermum. Stamens not eccentric. Fruit membranous, fleshy, coriaceous, or winged.

Trees or shrubs.

Whole plant densely villous with stellate hairs; leaflets deeply

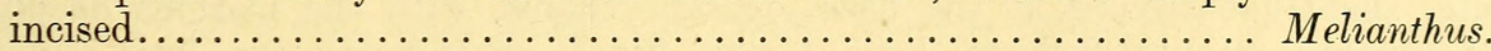

Plants most glabrous; leaves or leaflets never deeply incised.

Leaveș broadly ovate, palmately lobed; flowers scarlet...... Greyia.

Leaves or leaflets lanceolate or elliptic; flowers greenish or whitish.

Leaves simple.

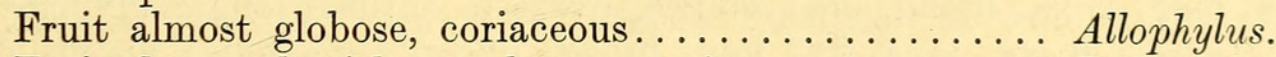

Fruit flattened with membranous wings.......... Dodonaea.

Leaves compound.

Leaflets unequal-sided; rachis with broad or narrow wings.

Young branches, leaf rachis, and inflorescence

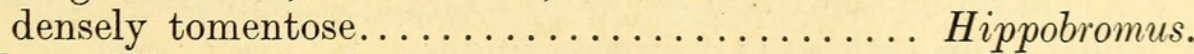

Plant glabrous or almost so............. Pteroxylon.

Leaflets not unequal-sided; rachis not winged, or only winged in the uppermost segment.

Leaves trifoliate; sepals glabrous, pedicels $1 \mathrm{~mm}$.

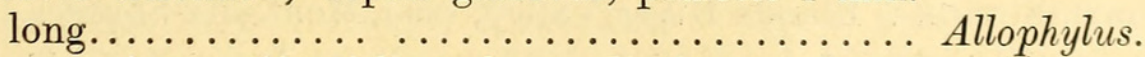

Leaves pinnate, if trifoliate then pedicels $1 \mathrm{~cm}$. long; sepals hairy.

Inflorescence a panicle up to $43 \mathrm{~cm}$. long.... Sapindus.

Inflorescence a raceme up to $17 \mathrm{~cm}$. long..... Bersama. 


\section{CARDIOSPERMUM LINN.}

\section{C. halicacabum Linn.}

A herbaceous climber. Stems deeply five-furrowed with prominent ridges, scantily pubescent. Leaves 3-6 cm. long, trifoliate, each leaflet of the first order digitately divided into three leaflets of the second order; petiole 1.5-1.8 cm. long, furrowed, pilose ; petiole of leaflets 8-11 cm. long, similar to the petiole of the leaf; ultimate leaf-segments $1 \cdot 5-2 \cdot 5 \mathrm{~cm}$. long, $0 \cdot 5-1 \cdot 3 \mathrm{~cm}$. broad, ovate or ovate-lanceolate, acute, hirsute above: glabrous beneath except on the veins, with the margins deeply cut into 2-3 lobes. Inflorescence a compound umbel with three principal peduncles, axillary; primary peduncle $3-7 \cdot 2 \mathrm{~cm}$. long, four-angled, pilose, and bearing at the apex two spirally-coiled tendrils; secondary peduncles $8-1 \cdot 7 \mathrm{~cm}$. long, scantily pubescent. Sepals unequal; the smaller $2 \mathrm{~mm}$. long, $2 \mathrm{~mm}$. broad, ovate, rounded above, glabrous ; the larger $5 \mathrm{~mm}$. long, 2-5 mm. broad, obovate, obtuse. Petals similar to the larger sepals. Stamens eccentric; staminal tube 1-5 mm. long; free portion of filaments $2 \cdot 5-3 \mathrm{~mm}$. long, linear, glabrous, sometimes ciliated; anthers $0.75 \mathrm{~mm}$. long, oblong. Ovary $3 \mathrm{~mm}$. long, eccentric, consisting of three carpels with a broad dorsal wing and a narrow ventral wing; style none ; stigmas three, ovate, concave. Torus between the stamens and ovary produced into two blunt lobes $5 \mathrm{~mm}$. long. Fruit 2-3-celled bladdery capsule with a single seed in each cell; the valves not veined and pubescent with bulbous base hairs. Seeds black, $4 \mathrm{~mm}$. long, $3.5 \mathrm{~mm}$. broad, somewhat globose, glabrous. Sonder in Harv. and Sond., Fl. Cap., 1, 237, Bot. Mag., t. 1049.

Natal: Verulam, March, Wood 483, and in Colonial Herb. 6795, without locality, Sanderson, Gueinzuis.

Distribution: Rhodesia, Pondoland, Transvaal, Bechuanaland Protectorate.

\section{M. villosus Bolus.}

\section{MELIANTHUS LINN.}

A herbaceous shrub. All parts densely covered with stellate hairs. Branches tomentose. Leaves petioled, compound, paripinnate, 5-7-jugate, 8-19 $\mathrm{cm}$. long; petiole $3 \cdot 2-5 \cdot 5 \mathrm{~cm}$. long, densely villous; leaflets $2 \cdot 5-7 \cdot 5 \mathrm{~cm}$. long, $6-3 \mathrm{~cm}$. broad, lanceolate, subacute, slightly narrowed at the base, densely villous, with the margins deeply and acutely serrate; stipules $2.2 \mathrm{~cm}$. long, $4 \mathrm{~mm}$. broad, ovate-lanceolate, long acuminate, acute, densely villous. Inflorescence a terminal raceme $28 \mathrm{~cm}$. long. Peduncle $12 \mathrm{~cm}$. long, densely villous. Bracts $2 \cdot 3 \mathrm{~cm}$. long, $1 \cdot 2 \mathrm{~cm}$. broad, ovate, long acuminate, pubescent. Pedicels $2 \mathrm{~cm}$. long, terete, villous. Sepals unequal; lateral sepals $2 \cdot 6 \mathrm{~cm}$. long, $1.3 \mathrm{~cm}$. broad, elliptic, obtuse, tomentose within and without; anterior sepal $1.6 \mathrm{~cm}$. long, $1 \mathrm{~cm}$. broad, boat-shaped, ovate in outline, long acuminate, densely tomentose. Petals $1.9 \mathrm{~cm}$. long, 2-3 mm. broad, linear, three-lobed above, densely pilose on the upper half, with the middle lobe tongue-shaped; the lateral lobes smaller, sometimes rudimentary. Disc in the form of flat fleshy glands 4-5 $\mathrm{mm}$. long, $2 \mathrm{~mm}$. broad, truncate at the apex. Filaments 6-9 mm. long, subterete, pilose; anthers $4.5 \mathrm{~mm}$. long, $2 \mathrm{~mm}$. broad, oblong. Ovary $4 \mathrm{~mm}$. long, pyramidal in outline, four-angled, glabrous, four-celled, each cell containing many ovules; style $5 \mathrm{~mm}$.long, subterete, somewhat falcate, narrowing to a blunt point, pubescent; stigma simple.

Natal : Rocky Hill, South Downs, 4000-5000 ft., December, Wood 1008, 4376, and in Natal Govt. Herb. 5133.

\section{Distribution : Elands River Valley, near Mont-aux-Sources.}

$M$. insignis, O. Kuntze. I have not seen specimens of this species, but from the short description given by Kuntze (Rev. Gen. III, 43) it may possibly be the same as M. villous Bolus. 


\section{$2 \mathrm{BHL}$ Biodiversity Heritage Library}

Phillips, E P. 1922. "THE NATAL SPECIES OF THE SAPINDACEAE." Bothalia 1, 57-58. https://doi.org/10.4102/abc.v1i1.1774.

View This Item Online: https://www.biodiversitylibrary.org/item/133653

DOI: https://doi.org/10.4102/abc.v1i1.1774

Permalink: https://www.biodiversitylibrary.org/partpdf/168120

\section{Holding Institution}

Smithsonian Libraries

\section{Sponsored by}

Biodiversity Heritage Library

\section{Copyright \& Reuse}

Copyright Status: Not in copyright. The BHL knows of no copyright restrictions on this item.

This document was created from content at the Biodiversity Heritage Library, the world's largest open access digital library for biodiversity literature and archives. Visit BHL at https://www.biodiversitylibrary.org. 